\title{
Linking Regional Science and Urban Economics: Long-Run Interactions among Preferences for Amenities and Public Goods
}

\author{
Philip E. Graves \\ Department of Economics University of Colorado, Boulder, USA \\ Email: Philip.Graves@Colorado.edu
}

Received February 2, 2012; revised February 18, 2012; accepted March 3, 2012

\begin{abstract}
The linked nature of long-term patterns of urban deconcentration and regional change (from rustbelt to sunbelt in the U.S., but with similar phenomena increasingly world-wide) is analyzed in a framework that emphasizes heterogeneous human preferences. The focus is on the important interactions that exist between local and regional amenities, whether exogenous or endogenous. The central thesis is that persistent exogenous amenity variation among regions provides an underlying pattern of regional growth and decline. However, inappropriate provision of local public goods in central cities is seen to lead both to non-optimally large levels of suburbanization and to rates of regional change that are also non-optimally large.
\end{abstract}

Keywords: Spatial Distribution of Economic Activity; Suburbanization; Regional Growth and Decline; Amenities; Local Public Goods

\section{Introduction}

Economists' key insight into human behavior is that observed choices stem from the interaction between preferences and opportunities. At any point in time, marginal costs temper, on the margin, our desires for specific goods, the former being exogenously determined by known technology. However, over time technology is itself importantly determined by preferences-the profitability of invention and innovation depends on basic human desires, whether this involves transportation technology or air conditioning.

The preceding observation has received little explicit emphasis in the study of long-term regional dynamics, in particular vis-à-vis linkages between regional science and urban economics. Questions of long-term dynamics of the urban/regional system are, of course, only one class of questions of interest in urban and regional research. For example, the relatively short-term regional employment and unemployment affects of changing national demand patterns have been, and continue to be, of great concern to many regional economists ${ }^{1}$. Early regional

\footnotetext{
${ }^{1}$ After numerous lengthy discussions about the relative importance of various causes of migration with Michael Greenwood, it gradually became clear that we were interested in different classes of questions. Mike and many other migration scholars (see, [1] for a review) have emphasized shorter run disequilibrium phenomena, such as arbitragible income or unemployment rate differentials, while my interests have centered on the long-run impacts of amenity differentials.
}

science models reflect this concern, invoking demanddriven basic employment, with supplemental local multiplier employment and shift-share analysis, later followed by input-output modeling and other approaches.

Interesting recent contributions to the understanding of relatively long-term regional population changes (see e.g. [2-4]) have focused on variables that facilitate or hinder regional and urban change. It is certainly the case that transportation advances have facilitated regional and urban change, while housing durability hinders such change.

However, these observations, while certainly both interesting and important, do not highlight the complex human preferences over spatially varying characteristics that are the root causes of observed urban and regional population patterns and trends.

Sjaastad's [5] classic paper laid out the theoretical underpinnings of migration in economic terms, arguing that a movement will occur when the net present value of the benefits exceed the net present value of the costs. His focus, however, was on wage differentials as representing real utility differentials. This "labor economics" view of migration would lead to expectations of wage convergence over time. In recent decades such convergence is either not happening or is occurring at implausibly slow rates given the amount of movement that is taking place.

Graves and Linneman [6] developed a consumption theory of migration that supplemented traditional job 
search motivations. Breaking goods into those that can be traded among areas and those that cannot, it was seen that only changing demands for the non-traded goods resulted in changed optimal locations, ceteris paribus. The probability of migration was shown to be importantly affected by changes in exogenous variables that alter demands for non-traded goods, in a probit regression analysis. Later work [7] using a multinomial logit model, revealed that both housing demand and more traditional job search motivations also significantly influence the decision to migrate. Moreover, it was also seen that both equilibrium and disequilibrium forces induce migration and job change, at least over the medium term.

Mueser and Graves [8] theoretically examined these issues and provided a county-level empirical analysis of migration occurring over the 1950-1980 period. With individuals and firms forming rational expectations about future opportunities, the level of migration is seen as a function of variations in factors influencing migrant labor demand ("economic opportunity") and migrant labor supply ("residential amenities"). They found that "systematic migration trends observed over several decades appear to have been tied to household preferences for amenities, in conjunction with changes in income or technology that increase the importance of such factors" ([8], p. 195). That is, small-but systematic_impacts of amenities on residential location choice cumulate over time, while the employment-related factors (e.g. spatial impacts of oil price shocks, pollution controls, or recessions) appear to exhibit modest intertemporal correlation.

\section{A Modeling Approach}

In light of introductory discussion and taking a very long-term perspective, the "chicken versus egg" debate (see [9-11]) is presumed here to be largely resolved, with jobs primarily following people rather than conversely. The trend toward falling costs of transporting manufactured goods emphasized in [3] along with persistent, continuing declines in manufacturing employment support this approach. Additionally, the growing importance of the service sector further supports the argument that such footloose employment would follow households. Moreover, over a sufficiently long period, the relative importance of arbitragible disequilibrium influences is likely to be muted vis-à-vis equilibrium forces ${ }^{2}$. Particularly in the past half-century in the United States (perhaps more recently in other parts of the world), the costs of migration have fallen (both out-of-pocket and psychological, since communication is so low-cost in the modern world) and the benefits of migration-in terms of knowledge about potential destinations - are widely known at low cost.

\footnotetext{
${ }^{2}$ For two very divergent views on the relative importance of equilibrium and disequilibrium influences on migration and regional change, see [12] and a rejoinder [13].
}

Hence, the focus here is on the role of human preferences for location in a long-run general equilibrium setting, elaborating on earlier models (see [14-20]).

In brief, the underlying notion of the preceding papers is that two types of goods exist, those that are tradable over space and those that are not, notably amenities such as climate (see $[17,21]$ ). Many of the wide array of consumption goods that enter utility can be varied in situ, but to vary the quantities consumed of other types of goods requires movement. Thus, with rising average real income nation-wide, the net demands for locations offering normal or superior amenities (e.g. climate amenities, reduced crime, better schools) will increase, while locations offering inferior amenities experience net decreases in demand. As nationwide incomes continue to rise, the utility value of the cumulative pent-up demands for location-specific amenities eventually offsets the cost of movement, resulting in migration. With birth/death-rates largely predictable, systematic migration patterns become the critical determinants in the prediction of long-term population patterns.

For present purposes, it is useful to expand the categories of non-tradable goods at location $\mathrm{j}$ that enter individual i's utility function:

$$
\mathrm{U}_{\mathrm{ij}}=\mathrm{U}\left(\mathrm{X}, \mathrm{RA}_{\mathrm{exj}}, \mathrm{RA}_{\mathrm{enj}}, \mathrm{LA}_{\mathrm{exj}}, \mathrm{LA}_{\mathrm{enj}}, \mathrm{S}, \mathrm{L}\right)=\mathrm{U}^{*}
$$

where $\mathrm{X}=$ tradable consumption goods,

$\mathrm{RA}_{\mathrm{exj}}=$ regionally-varying exogenous amenities (e.g. climate at $\mathrm{j}$ ),

$\mathrm{RA}_{\mathrm{enj}}=$ regionally-varying endogenous amenities or disamenities (e.g. region-wide cultural opportunities, congestion or pollution at $\mathrm{j}$ ),

$\mathrm{LA}_{\mathrm{exj}}=$ locally-varying exogenous amenities (e.g. access to ocean or $\mathrm{CBD}$ at $\mathrm{j}$ ),

$\mathrm{LA}_{\text {enj }}=$ locally-varying endogenous amenities or disamenities (e.g. school quality or crime levels at j),

$\mathrm{S}=$ space (lotsize), and

$\mathrm{L}=$ leisure.

Heterogeneous households maximize this utility function subject to a full income budget constraint in which the four types of (bundled) amenities are priced hedonically in land and labor markets (see [22-25]) ${ }^{3}$. A full hedonic equilibrium would leave utility equal, at $\mathrm{U}^{*}$ in Equation (1), for each type of household, in all locations. Indeed, the necessary combined compensation in land

\footnotetext{
${ }^{3}$ The extent to which hedonic compensation for amenities occurs in land relative to labor markets is complicated. A location that is unusually (exogenously) nice for households would in equilibrium, other things equal, have higher rents and lower wages (and, generally, higher levels of endogenous disamenities such as congestion or pollution). This follows from the in-migration necessary to obtain a common utility level over space. However, variations in production amenities affecting the cost function modifies this expectation, since locations desirable for firms would possess both higher rents and wages, ceteris paribus. Nonetheless, one might generally expect a higher proportion of the region-wide amenity compensation to occur in wages, while local amenity variation is likely to occur primarily in land markets.
} 
and labor markets is an appropriate measure of "quality-of-life" variation over space (see [26] for the first multi-market empirical estimates of quality of life).

In this equilibrium framework, changes in prices facing a household or changes in its income result in revised amounts of tradable and non-tradable goods demanded. The invention and widespread use of air conditioning, for example, provides a price change encouraging movement toward locations that were previously undesirably hot in summertime. Similarly, rising incomes might lead to demands for more sunshine and warmth by those in the Midwest or Northeast, leading ultimately to moves to satisfy revised demands for such non-tradable amenities. Such moves will, in turn, lead to revised compensating differentials in a moving equilibrium.

The heterogeneity of preferences is important to an understanding of regional location patterns. As first observed in Ravenstein's [27] fourth "law of migration," high net in-or-out-migration in a locale is comprised of high gross flows in both directions. This is quite an unexpected finding from the perspective of the wage-search models of labor economics. While one might attribute this to some informational inefficiency of migration flows (see [28]), a more compelling long-run story relies on heterogeneity of households in the urban/regional equilibrium setting focused on here. First, and most obvious, rising average national income does not mean each household experiences rising income. Hence when those with rising incomes would be moving into desirable regions, while those with falling incomes might be expected to be leaving such regions (see [6] for more theoretical detail).

Of likely greater importance are the changes in wages, rents, and endogenous amenity levels that result when in-migration into desirable locations takes place. Those moving in will tend to drive up rents, drive down wages, and increase regional congestion/pollution, holding constant policy responses. All of these changes lead to outmigration of sensitive, affected groups. Finally, individuals at different life-cycle stages can have different optimal locations, as for example, retirees moving to locations in which amenities are largely priced in labor markets in which they no longer participate (see [29]).

The optimal values of the arguments of the utility function of Equation (1) are functions of all prices in the system, along with wages and non-earned income. The per square foot price of space, S, embeds the land component of hedonic compensation for all amenities, regional or local, endogenous or exogenous. The wage rate embeds the labor component of hedonic compensation for the four amenity categories.

\section{The Dynamic Regional Patterns}

The model sketched in the previous section leads to re- gional changes that are in the nature of "moving equilibria" in which changing opportunities and incomes lead to changes in location necessary to arbitrage otherwise emergent spatial variation in utility. What are the important dynamic regional patterns to be understood within such a model?

Confining discussion to the post-1960 period in the United States ${ }^{4}$, there have been two dominant trends (see $[3,30])$ :

Population movement from the Northeast and North Central regions to the West and, more recently, toward the South.

Continued decentralization of metropolitan area population and employment, with greater suburbanization and non-metropolitan growth, again with reversals in very recent periods.

The first trend, movement from the rustbelt to the sunbelt, is primarily due to the changing demands for climate and other amenities (see [31] on the latter). Rising incomes led to Westward movement that in turn resulted in growth in endogenous disamenities (e.g. region-wide pollution and congestion) along with rapidly rising rents in many constrained destinations in the West. These endogenous feedbacks, along with the spread of air conditioning, resulted in redirection of the population flows to initially less attractive Southern destinations.

However, more is going on, since the dominant trends will be shown here to be interdependent. Movement costs have a fixed and a variable component, the latter being most strongly related to distance moved. A central city household with rising income, hence increased demand for local amenities, might wish to consider a move to a suburb of that city. But that household may be unable to justify, with local amenity consumption gains, even a moderately short distance move because of the high fixed costs of relocating. A possibly large utility gain from moving to the suburbs of a distant region with improved climate, however, might offset both the fixed costs and the incremental variable costs of that move. That is, central cities of the rustbelt not only lose population to their suburbs but also lose population to suburbs in other regions. Thus, any forces that increase the rate of suburbanization are likely in addition to speed up broader regional growth trends.

\section{Are the Dynamic Patterns Optimal?}

\section{Suburbanization Inefficiencies:}

\footnotetext{
${ }^{4}$ The model of Section II applies more broadly, recognizing that the vector of ordinary tradable goods available for consumption was importantly limited by transportation costs in earlier periods, periods dominated by water transport to and from large coastal/river cities, with interior production primarily concentrated on extractive industries. The transportation constraints have become less inhibiting to fundamental human preferences, and the importance of extractive industries has declined, over time.
} 
Pursuing this more fully, one might ask, "Are observed urban and regional population patterns socially desirable?” Pursuing pleasant climates in other locales seems unambiguously reasonable to the economist, but is the observed degree of suburbanization optimal? Glaeser and Kahn [2] argue that suburban sprawl is largely benign, though they cite a number of papers arguing otherwise (e.g. [32-35]). If, as argued here, suburbanization is occurring at non-optimally large rates, broader regional changes must also be occurring at non-optimally large rates as discussed above.

Non-economists are almost unanimously against suburban sprawl, while economists generally are more ambivalent. Indeed, [2] argues that "the problem of sprawl lies not in the people who have moved to the suburbs but rather the people who have been left behind ${ }^{5}$." The issue, as seen by the economist, is quite complex and hinges critically on the nature of externalities. If all externalities (crime, air and water pollution, congestion, noise, and so on) were properly internalized in each separate market, the economists' presumption would be that there would be no role for urban planners; they could only make things worse. Observed suburbanization, however large, would be optimal. Indeed, revealed preference carries a great deal of weight among economists, and the possibly large private benefits of suburbanization, discussed by Glaeser in the several co-authored papers mentioned here, might well offset any negative externalities associated with that suburbanization.

In the context of Equation (1), the central issue revolves around two questions. The first is whether suburban locations are being chosen only on the basis of a trade-off between optimal lotsize and commuting costs, ignoring the levels of public goods that are often concomitant with locational choice. The second question is whether the spatial array of public goods, over which households make such choices, is itself optimal.

As to the first question, it seems clear that the reason many, if not most, people move to the suburbs in the United States, and probably many other countries, is not closely related to lotsize and commuting cost trade-offs, per se. Rather, people are escaping low provision levels of local public goods in the central cities, the $\mathrm{LA}_{\mathrm{enj}}$ of Equation (1)—poor school quality, high crime, pollution, insufficient parks, and so on.

I argue in this section that much of the high rate of suburbanization we observe is socially non-optimal, due ultimately to failure to provide proper levels of local public goods in our central cities. Moreover, the forces that lead to excessive suburbanization have non-optimally increased the speed of population flows to the South and

\footnotetext{
${ }^{5}$ That identical people types would be expected to have essentially the same utility levels over the central city versus suburban residence choice renders this conclusion suspect, though, as discussed further in the text.
}

West. The private market equilibria that are the focus of traditional urban models (e.g. [36,37]) are seen here to result in excessive suburbanization with population densities that are too low in the urban centers.

The basic argument on pure public goods provision is simple (see [38,39], the latter representing a some- what different endogeneity argument that supplements the former). Since Samuelson's [40] explication of optimal public good provision, concern has revolved around free riding behavior in output markets. The incentive to free ride, due to non-excludability, means that public goods will not be optimally provided privately. At issue is how to create an incentive mechanism that yields true individual public good values, as necessary to obtain the marginal benefits, via aggregation, of public goods (see $[41,42])$.

With full demand revelation out of existing income, something Samuelson was not optimistic about observing, he argued that vertical summation of individual demands for pure public goods would yield the aggregate marginal benefit appropriate to compare to the marginal costs of provision. Pursuing this rule, implicit in benefit-cost analysis for long-term projects, would seem to result in the proper relative amounts of public and private goods, since vertical summation of demands for public goods is the analog to horizontal summation of demands for private goods.

However, the situation away from a true Samuelson optimum optimorum is more complicated than has been realized. At the core of economics is the presumption that we work, giving up leisure, to get the goods that we desire. When we cannot increase our consumption of the goods we care about by generating greater income, we will just "buy" more leisure ${ }^{6}$ To the extent that households care about ordinary goods, the $\mathrm{X}$ vector of Equation (1), they will have an incentive to generate income. However, to the extent that they care about pure public goods (e.g. a saved species or a marginal increment to air or water quality), they will realize that the income they generate will not influence the collectively determined amounts, hence they will not generate that income because leisure is valuable. Consequently, the incomes used in all applied benefit-cost analyses of the provision of pure public goods are too low, and such goods are under-provided ${ }^{7}$. Indeed, all of the ungenerated income

\footnotetext{
${ }^{6}$ The text observation is related to some reasons advanced for the decline of the Soviet Union and other planned economies in which the link between work effort and work reward was weakened or broken. This explains, for example, the poor collective farm performance vis-à-vis the much more productive private farms in which the work-reward link was stronger. Public goods, determined collectively, provide an extreme case in which individual work effort is unrelated to increments in individual consumption.

${ }^{7}$ Ironically, since value in economics is synonymous with marginal willingness-to-pay, those with the very highest relative demands for pure public goods will appear to have the lowest demands for anything - in extreme cases becoming the hippie dropouts of the '60s.
} 
would have been spent on public goods, apart from general equilibrium effects.

What has the theory of pure public goods provision to do with urban and regional location patterns? Public goods come in many varieties, with pure public goods (e.g. a saved species providing benefits to all or $\mathrm{CO}_{2}$ abatement) being rare. More typical are locationally varying levels of endogenous amenities such as school quality, local crime, and the like- the $L A_{\text {enj }}$ of Equation (1). Such goods often have private goods substitutes in situ (e.g. elaborate locks or security systems in high crime locales or private schools as substitutes for low-quality public schools). However, one important way to substitute from a low central city endogenous amenity bundle is to purchase, through relocation, the amenity bundle offered in a suburban location (see [35] for detail).

As discussed in [43] Graves (2009b), even with perfect demand revelation out of current income, there are an infinite number of apparent Samuelson optima, one for each level of free riding in input markets. A path dependence argument strongly suggests that we are unlikely to be near the one true optimum optimorum; rather, there is likely to be free riding in input markets, with resulting under-provision of locally varying public goods. That is, even the public good provision levels of an ideal central city government-one with perfect demand revelation out of current income and no public choice incentive problems-would be too low. The levels would be based on current income levels in the benefit-cost analyses, rather than optimal income levels. Hence, even if aggregated (apparent) marginal willingness to pay equaled marginal cost of provision for every public good in the urban core, the extent of any remaining suburbanization would still be non-optimally large.

Pursuing this further, consider individuals living in the urban core. The urban core typically has many problems (crime, pollution, congestion, noise, lack of open space, etc.) that are, at least partially, of a local public good nature. Non-optimally low levels of such public goods are provided in the urban core, with core residents under-generating income ${ }^{8}$.

There are generally more private market substitutes for locally varying public goods than for pure public goods (e.g. parks versus species preservation). This is because their provision is profitable since one cannot "free ride" if consumption of the locally varying public good requires the purchase of the land offering the public good. The Tiebout [44] model provides a mechanism by which

\footnotetext{
${ }^{8}$ It should be noted that if perfect private good substitutes existed for all public goods, the correct amount of income would be generated and the, now larger, flow of private goods would be purchased with the larger incomes generated. Perfect private market substitutes effectively eliminate the public goods problem; income generated would be optimal, the proper amounts of all goods would be produced, and there would be no problems of either output demand revelation or input market failure, the latter emphasized here.
}

local public goods can be efficiently provided if there are sufficiently many jurisdictions, without important jurisdictional spillovers or scale economies ${ }^{9}$.

However, the prospect of a perfect Tiebout world is extremely dubious in the present spatial context. This follows from the bundling of both non-governmental (e.g. access to the center) and governmental location-specific public goods of a large number and variety. Such bundling inevitably results in an internal contradiction. The contradiction stems from three mutually inconsistent requirements in the model. First, there must be many jurisdictions to allow each household to find its perfect bundle of local public goods. However, with many jurisdictions, cross-jurisdictional spillovers would defeat that efficiency. That is, desires for a specific, say low, level of crime in one jurisdiction would be expected to drive criminals into nearby jurisdictions, or a polluter at the downwind edge of one jurisdiction might prevent those in an adjacent jurisdiction from acquiring the air quality they desire. The presence of scale economies compounds this problem in the provision of some local public goods.

Hence, jurisdictions will always be either too large, too small (and, typically, both simultaneously, depending on the public good involved), or in the wrong place (e.g. too far from the center) from the standpoint of heterogeneous household demands for particular local public goods bundles. By way of illustration, a location that is close to the center, in a school district with high-quality schools, with clean air and spacious parks might well not exist (there will inevitably be non-convexities, multiple equilibria, and so on).

While not perfect, though, a Tiebout-like spatial substitute for directly improving levels of urban crime, air quality, noise, and congestion, and so on is provided by the option of moving to the suburbs. Consequently, many people will generate the income to acquire the higher levels of some local public goods in the suburban areas. Suburbanization, with associated lengthy commutes and reduced private and public consumption choices (restaurants, cultural amenities, etc.) is, however, a poor substitute for direct increases in the provision of urban public goods. And, in the cases of some public goods (e.g. regionwide pollution in areas such as LA), suburbanization might fail to deliver much in improved consumption levels, relative to the desires of the residents. The inability to disbundle will imply that the perfect private good substitute does not exist for local central city public goods.

\footnotetext{
${ }^{9} \mathrm{~A}$ desirable feature of the Tiebout model is that it offers a possible solution to the inefficiencies associated with majority voting as a means of deciding the levels of public goods to provide in a world of taste heterogeneity. It is, interestingly, an even better solution to median voter efficiency problems than has been realized. Voting "with one's feet" will require that individual households generate the income, in competition with others, to acquire local public goods, hence they will generate that income. But only in a perfect Tiebout world (unlikely) will the proper income be generated, as discussed in the text.
} 
Hence failure to generate the right amount of income remains, along with non-optimal movement to the sub$u b^{10}{ }^{10}$. This result holds even with perfect demand revelation out of current income, perfect information, and perfect political institutions in applying the Samuelson aggregation rule.

More formally, assume initially that all households are located in one giant homogeneous central city, effectively ignoring the spatial nature of both cities and regions. The representative agent will have failed to give up leisure to generate income to buy public goods, even if that agent has very high marginal benefits of such goods, because doing so will not enable any more of the good to be acquired. City residents will have adjusted leisure (and private goods), whose benefits they can capture by foregoing income, purchasing more of each than is optimal ${ }^{11}$. That is, employing the symbols and structure of Equation (1):

$$
\begin{aligned}
& \mathrm{U}_{0}=\mathrm{U}\left(\mathrm{X}_{0}, \mathrm{RA}_{0 \text { exj }}, \mathrm{RA}_{0 \text { enj, }}, \mathrm{LA}_{0 \text { exj }}, \mathrm{LA}_{0 \text { enj }}, \mathrm{S}_{0}, \mathrm{~L}_{0}\right) \\
& \ll \mathrm{U}\left(\mathrm{X}^{*}, \mathrm{RA}_{0 \text { exj }}, \mathrm{RA}_{0 \text { enj }}, \mathrm{LA}_{0 \text { exj }}, \mathrm{LA}_{\text {enj }}^{*}, \mathrm{~S}^{*}, \mathrm{~L}^{*}\right)=\mathrm{U}^{*}
\end{aligned}
$$

where, under independence, $\mathrm{X}_{0}>\mathrm{X}^{*}, \mathrm{~L}_{0}>\mathrm{L}^{*}, \mathrm{~S}_{0}=\mathrm{S}^{*}$, $\mathrm{LA}_{0 \text { enj }}<\mathrm{LA}_{\text {enj }}^{*}$, and the double inequality indicates that a potentially large disparity exists between the constrained utility values (when the public good cannot be purchased with incremental income) and the unconstrained values ${ }^{12}$. Lot-size, S, is assumed for simplicity to be the same in this initial case with a fixed number of people and in the absence of suburbs ${ }^{13}$.

Now, introduce suburbanization possibilities-but without yet allowing variation in regional amenitieswith suburbanization providing a (poor) substitute for in situ provision of local public goods. We will observe a

\footnotetext{
${ }^{10}$ There are many good reasons, unrelated to local public goods provision, why particular households might wish to locate in the suburbs (bigger lots for large families, demands for access to the countryside and so on). This is not critical to the argument, in the sense that the text claims about inappropriate urban local public goods provision are overlaid upon whatever other reasons for suburbanization exist. The qualitative implication that more suburbanization occurs than is socially desirable continues to hold.

${ }^{11}$ The text discussion implicitly assumes that private and public goods are independent (e.g. as would be the case with Cobb-Douglas utility functions). More general cases are discussed in Flores and Graves 2008 in the context of endogenizing the labor/leisure decision when public goods are varied.

${ }^{12}$ Note that the disparity might have been relatively small when we first began providing public goods collectively. For example, when environmental programs were first promulgated, as the environment quality freely available from nature came to be viewedas inappropriately low, the spread between optimal and actual utility might have been small. But, as income and population have grown over time, the marginal values of public goods relative to those of the ever-increasing quantities of private goods has doubtless risen sharply.

${ }^{13}$ It is possible that the portion of private goods that are housing-related will imply larger lot-sizes before optimal public goods provision, though this is not critical to the argument. When suburbs begin to exist, equilibrium lot-sizes will become larger at the edge for the usual monocentric reasons.
}

utility-enhancing (relative to $\mathrm{U}_{0}$ ) increase in optimal levels of income generated to buy in private land markets the higher levels of local public goods available in the suburbs. In the traditional monocentric urban modeling context, the additional income will be buying not only higher (but not necessarily optimal) levels of local public goods, but will also be buying longer commute times, a joint bad. Additionally, suburban residents will be foregoing other desirable aspects of locating at the urban center (ocean or river access in many cases as well as density-dependent goods such as restaurant variety or cultural activities). Since rent compensation would result in equilibration of utility of like households across the city (subscripted with a C) versus suburban (subscripted with an S) location choice, we have:

$$
\begin{aligned}
& \mathrm{U}_{0}=\mathrm{U}\left(\mathrm{X}_{0}, \mathrm{RA}_{\text {0exj }}, \mathrm{RA}_{\text {0enj }}, \mathrm{LA}_{\text {0exj }}, \mathrm{LA}_{\text {0enj }}, \mathrm{S}_{0}, \mathrm{~L}_{0}\right) \\
& <\mathrm{U}\left(\mathrm{X}_{\mathrm{S}}, \mathrm{RA}_{\text {0exj }}, \mathrm{RA}_{\text {0enj }}, \mathrm{LA}_{\text {Sexj }}, \mathrm{LA}_{\text {Senj }}, \mathrm{S}_{\mathrm{S}}, \mathrm{L}_{\mathrm{S}}\right) \\
& =\mathrm{U}\left(\mathrm{X}_{\mathrm{C}}, \mathrm{RA}_{\text {0exj }}, \mathrm{RA}_{\text {0enj }}, \mathrm{LA}_{\text {Cexj }}, \mathrm{LA}_{\text {Cenj }}, \mathrm{S}_{\mathrm{C}}, \mathrm{L}_{\mathrm{C}}\right) \\
& \ll U\left(X^{*}, R_{0 e x j}, R_{0 \text { enj }}, L_{0 \text { exj }}, L_{\text {enj }}^{*}, S^{*}, L^{*}\right)=U^{*}
\end{aligned}
$$

That is, the utility associated with moving to the suburbs will be greater than if that option were unavailable, but there is still a potentially large divergence between utility at either suburb or center vis-à-vis optimal in situ central city public goods provision. Rents in the suburbs will be bid up from initial agricultural levels, while those in the city will fall somewhat, as people move to the suburbs. The lot-sizes will be larger in the suburbs than in the center, that is, $\mathrm{S}_{\mathrm{S}}>\mathrm{S}_{\mathrm{C}}$. Whether income generated and goods consumption in the suburbs will be greater than under the case of optimal in situ central city public goods provision is ambiguous ${ }^{14}$.

The problem, at heart, is one of inability to disbundle locally provided public goods, including access in particular. To get higher levels of environmental or school quality by buying a suburban substitute location, one must accept lower levels of access to work and entertainment. Suburbanites are unable to buy exactly what they want, but only some of the things they want, by the very nature of space ${ }^{15}$.

How great is the empirical relevance of over-suburbanization likely to be in the "real world?" The hedonic compensation argument that yields the middle equality in

\footnotetext{
${ }^{14}$ It would seem clear, however, that issues of what is a "good" versus a "necessary bad" that appear in discussions of national income accounting would become quite relevant in this setting. Moreover, the same type of consideration would apply to leisure activities. Consider, for example, increased commuting that draws equi-marginally from work and other leisure activities. The increased commuting would both raise GDP and increase official measurements of "leisure," but would hardly be seen as a good thing by typical commuting households.

${ }^{15}$ Additional trips to the center and lunchtime or after-work activities alter the quantitative, but not qualitative, importance of being generally unable to purchase the desired local public goods bundle.
} 
Equation (3) is instructive. With fully informed people and no exhaustion of people-types on the margin, the rents or property values at the suburban fringe must leave identically-situated households with the same utility in the suburbs as those at the urban center. But, those remaining in the center continue to consume the sub-optimal amounts of the many local public goods that drove many others to suburbia - the only reason they are better off is that the suburban exodus will have lowered their rents somewhat ${ }^{16}$.

Hence, commuting costs and losses of densitydependent and any exogenous central city public goods largely offset the gains in utility from higher levels of certain public goods associated with moving to the suburbs. People will have generated more income to pay the commuting costs of movement to the suburbs to get the local public goods they so desperately want, but they do not really receive large utility gains. Rather, while greatly changing their behavior in terms of what they buy, people move along a utility surface that is only slightly shifted outward by movement to the suburbs. Hedonic compensation, if full, guarantees that; there will, of course, be sorting with perhaps entire groups exhausted at the center, hence there could be a non-negligible utility gain to some suburban movers. Provision of the proper amounts of public goods at the center is, however, clearly preferred to observed patterns of suburbanization.

Urban and Regional Inefficiencies:

Suppose now that we introduce large-scale regional amenities and a system of cities into the analysis. As discussed at the outset, variations in regional amenities such as climate importantly shape long-run regional population patterns as rising nationwide incomes lead to greater demands for non-traded amenities that can only be exercised by moving. However, for present purposes, it is useful to focus on the implications of over-suburbanization on broader regional population patterns.The large cities in the Northeast and North Central regions of the U.S. will have become over-suburbanized due to non-optimally low levels of central city public goods. This leaves the households, characterized as in Equation (3), with four options for improving their initial welfare levels. Both central city residents and suburbanites in the rustbelt can move to either suburbs or central cities in the Sunbelt ${ }^{17}$. This provides a rich tapestry of possible regional patterns of migration, in light of the heterogeneity of households and in the presence of four different types of amenities-local, regional, exogenous, and endogenous. Those with a particular dislike for commuting or strong preferences for density-dependent goods might move

\footnotetext{
${ }^{16}$ Indeed, suburban flight may cause added losses in some urban amenities, partially offsetting rent reductions.

${ }^{17}$ This movement will be selective of the more educated and younger households, leaving behind an older, more immobile population in the origin areas.
}

from central Chicago to central San Francisco. Others might move from a Cleveland suburb to a Phoenix suburb, consuming more climate amenities. Variations in the exogenous and endogenous supply of central city amenities will favor some urban areas, these effects being overlaid upon broader regional amenities.

Of particular interest here is that the potential utility gains of a move to the Sunbelt are larger, for households initially in either the suburbs or the central cities of the rustbelt, than they would be if public goods were properly provided in central cities of the rustbelt. This implies that the inter-regional migrant flows are likely to be non-optimally large - the rustbelt cities are declining too rapidly, while Sunbelt cities are growing too rapidly. Regional growth patterns are linked to urban population patterns.

\section{Summary and Conclusions}

The perspective of the present paper is very long run in nature. To understand more clearly such a perspective, it is useful to imagine a hypothetical scenario in which the United States is discovered on the West Coast, say in what were to become Los Angeles or San Francisco. Moreover, think of the equivalent of Europe in 1492 as lying to the west rather than to the east. What would one suspect that the population patterns of the United States would look like early in the $21^{\text {st }}$ Century? It would be plausible to suspect that a very large fraction of our population would be along the West Coast-and it would be implausible to imagine many people in places such as Rochester, Buffalo, or Detroit. Chicago and New York would likely be smallish trading centers akin to smaller versions of Seattle. This is the long run as envisioned in the context of the model of Equation (1).

As emphasized in [4], the durability of housing greatly slows the decay of cities in undesirable regions. As they express it, "...the key question about these declining cities is not “why aren't they growing?” The key question is "why are they still there at all?" So, while the automobile has facilitated intra-and-inter-regional migration, as is emphasized in [3], housing stock durability is a powerful deterrent to the realization of the hypothetical scenario envisioned above. This is because when demand falls for housing in a region, the fixity of the stock of housing implies that it is rents and property values that fall, potentially to quite low levels. Note that under the "West Coast discovery" scenario there would still be under-provision of locally varying public goods, resulting in oversuburbanization. That over-suburbanization would, in turn, lead to greater population levels in the undesirable regions than would be the case with optimal central city public goods provision.

Looking at suburbanization, history is what it is. How do we decide, now that suburbanization has proceeded at non-optimally high rates for many decades, where to 
supply marginal increments in local public goods? We can improve street lighting or crime rates in the central city or in the suburbs-where should the public goods be supplied now? The spatially optimal distribution of public goods (of an amount of public goods much larger than an apparent Samuelson optimum, out of current income) would be likely to place those goods in central urban areas. This follows from that fact that, for any given marginal cost, central city provision has higher marginal benefits due to higher population densities ${ }^{18}$.

Pondering the longer-run implications of providing the urban core public goods in situ rather than requiring the purchase of poor substitutes at the suburban fringeoffers further insight into the advantages of properly valuing public goods. Were clean air, noise abatement, quality schools, reduced congestion and the like provided directly in the right amounts in the central core, the net associated cost increases (and income generation increases) might not be as large as one might initially surmise. As mentioned earlier, people are already generating much income to buy poor suburban substitutes for urban public goods ${ }^{19}$.

Intra-regionally, the enhanced values of central locations would raise rents and property values in the center relative to the suburban fringe. This would have the long-run effect of encouraging greater density as capital is substituted for the relatively more expensive land at the center. This, in turn, would facilitate the spread of viable mass transit, including just walking, as opposed to the current situation that tends increasingly to discourage alternative transport modes over time. The greater population density would allow many (or perhaps all ${ }^{20}$ ) cities to enjoy the kinds of cultural and restaurant amenities now taken for granted in only a few urban areas. Indeed, if the correct amounts of public goods were provided in central locations, the principle determinant of suburbanizetion would be the income elasticity of demand for lot-size relative to the income elasticity of commuting costs, independent of the local suburban public goods that are at present positively correlated with lot-size.

Inter-regionally, property values in desirable destinations would be lower (and property values in undesirable

\footnotetext{
$\overline{{ }^{18} \text { Current population densities, of course, bear no relation to what they }}$ would be if urban public goods had been optimally supplied over time. One might speculate densities like that of Tokyo would not be considered unduly densely settled if urban public goods had always been provided optimally, but policy approaches for some public goods (noise pollution, for example) might also involve less-dense living schemes, as could income effects on lot-size. The net impact on average urban density would seem to be clear, however.

${ }^{19}$ For example, providing quality urban public schools would eliminate the expenses associated with sending children to private schools currently for many occupying the urban centers. Additionally, it would allow those who moved to the suburbs for better schools to return to the center, saving commuting and other costs.

${ }^{20}$ Some smaller cities might reasonably be expected to disappear when larger urban areas are as desirable as they would be under a longer-term scenario.
}

areas higher) with the slower rate of in-migration from rustbelt to Sunbelt, if central cities in the rustbelt provided proper public goods levels. At present, the shortrun moving equilibrium involves relatively high rents in cities and suburbs in desirable regions, made necessary to equilibrate utility there with similar households in both suburban and central city locations in undesirable regions.

The present paper suggests that economists, environmentalists, urban planners and others that are concerned about urban and regional population location and relocation might have more in common than has been traditionally perceived. Suburbanization has been occurring for many decades. This suburbanization has been widely vilified, but with arguments that were unconvincing to many economists. The present paper provides an argument that suburbanization has proceeded, and continues to proceed, at too rapid a rate. Moreover, the non-optimal suburbanization has also stimulated overly rapid out-migration to desirable regions.

The high post-WWII growth in income and population (combined with the input market failures emphasized here) would suggest that far higher levels of local goods should have been, and should be, provided in our large urban areas. Producing those endogenous local public goods at optimal levels would not only result in reduced rates of suburbanization, but would slow the optimal rate of growth in desirable regions, while slowing regional decline in undesirable regions.

\section{REFERENCES}

[1] M. J. Greenwood, "Research on Internal Migration in the United States: A Survey,” Journal of Economic Literature, Vol. 13, No. 2, 1975, pp. 397-433.

[2] E. L. Glaeser and M. E. Kahn, "Sprawl and Urban Growth,” Working Paper 9733, 2003. http://www.nber.org/papers/w9733

[3] E. L. Glaeser and J. E. Kohlhase, "Cities, Regions and the Decline of Transport Costs," Papers in Regional Science, Vol. 83, No. 1, 2003, pp. 197-228.

[4] E. L. Glaeser and J. Gyourko, "Urban Decline and Durable Housing,” Working Paper 8598, 2001. http://www.nber.org/papers/w8598

[5] L. A. Sjaastad, "The Costs and Returns of Human Migration,” Journal of Political Economy, Vol. 70, No. 5, 1962, pp. 80-93. doi:10.1086/258726

[6] P. E. Graves and P. D. Linneman, "Household Migration: Theoretical and Empirical Results," Journal of Urban Economics, Vol. 6, No. 3, 1979, pp. 383-404. doi:10.1016/0094-1190(79)90038-X

[7] P. D. Linneman and P. E. Graves, "Migration and Job Change: A Multinomial Logit Approach,” Journal of Urban Economics, Vol. 14, No. 3, 1983, pp. 263-279. doi:10.1016/0094-1190(83)90009-8 
[8] P. R. Mueser and P. E. Graves, "Examining the Role of Economic Opportunity and Amenities in Explaining Population Redistribution,” Journal of Urban Economics, Vol. 37, No. 2, 1995, pp. 176-200.

doi:10.1006/juec.1995.1010

[9] R. Muth, "Migration: Chicken or Egg?” Southern Economic Journal, Vol. 37, No. 3, 1971, pp. 295-306. doi:10.2307/1056181

[10] M. J. Greenwood and G. L. Hunt, "Migration and Interregional Employment Redistribution in the United States," American Economic Review, Vol. 74, No. 5, 1984, pp. 957969.

[11] M. J. Greenwood and G. L. Hunt, "Jobs Versus Amenities in the Analysis of Metropolitan Migration,” Journal of Urban Economics, Vol. 25, No. 1, 1989, pp. 1-16. doi:10.1016/0094-1190(89)90040-5

[12] A. W. Evans, "The Assumption of Equilibrium in the Analysis of Migration and Interregional Differences: A Review of Some Recent Research," Journal of Regional Science, Vol. 30, No. 4, 1990, pp. 541-546. doi:10.1111/j.1467-9787.1990.tb00119.x

[13] P. E. Graves and P. R. Mueser, “The Role of Equilibrium and Disequilibrium in Modeling Regional Growth and Decline: A Critical Reassessment," Journal of Regional Science, Vol. 33, No. 1, 1993, pp. 69-84. doi:10.1111/j.1467-9787.1993.tb00211.x

[14] B. Cushing, "A Note on Specification of Climate Variables in Models of Population Migration,” Journal of Regional Science, Vol. 27, No. 4, 1987, pp. 641-649. doi:10.1111/j.1467-9787.1987.tb01186.x

[15] D. B. Diamond and G. S. Tolley, "The Economics of Urban Amenities,” Academic Press, New York, 1982.

[16] P. E. Graves, “A Reexamination of Migration, Economic Opportunity, and the Quality of Life,” Journal of Regional Science, Vol. 16, No. 1, 1976, pp. 107-112. doi:10.1111/j.1467-9787.1976.tb00954.X

[17] P. E. Graves, “A Life-Cycle Empirical Analysis of Migration and Climate, by Race,” Journal of Urban Economics, Vol. 6, No. 2, 1979, pp. 135-147. doi:10.1016/0094-1190(79)90001-9

[18] P. E. Graves, "Migration and Climate," Journal of Regional Science, Vol. 20, No. 2, 1980, pp. 227-237. doi:10.1111/j.1467-9787.1980.tb00641.x

[19] P. E. Graves, "Migration with a Composite Amenity: The Role of Rents,” Journal of Regional Science, Vol. 23, No. 4, 1983, pp. 541-546. doi:10.1111/j.1467-9787.1983.tb01009.x

[20] G. S. Tolley, "The Welfare Economics of City Bigness," Journal of Urban Economics, Vol. 1, No. 3, 1974, pp. 324345. doi:10.1016/0094-1190(74)90011-4

[21] R. J. Cebula and R. K. Vedder, "A Note on Migration, Economic Opportunity, and the Quality of Life,” Journal of Regional Science, Vol. 13, No. 2, 1973, pp. 205-210. doi:10.1111/j.1467-9787.1973.tb00395.x

[22] D. R. Haurin, "The Regional Distribution of Population, Migration and Climate," Quarterly Journal of Economics, 95, 1980, pp. 293-308. doi:10.2307/1885501

[23] S. Rosen, "Wage-Based Indexes of Urban Quality of Life,"
In: P. Mieszkowski and M. Straszheim, Eds., Current Issues in Urban Economics, Johns Hopkins University Press, Baltimore, 1979, pp. 74-104.

[24] J. Roback, “Wages, Rents, and the Quality of Life,” Journal of Political Economy, Vol. 90, No. 6, 1982, pp. 12571278. doi: $10.1086 / 261120$

[25] J. Roback, "Wages, Rents, and Amenities: Differences among Workers and Regions,” Economic Inquiry, Vol. 26, No. 1, 1988, pp. 23-41. doi:10.1111/j.1465-7295.1988.tb01667.x

[26] G. C. Blomquist, M. C. Berger and J. P. Hoehn, "New Estimates of the Quality of Life in Urban Areas," American Economic Review, Vol. 78, No. 1, 1988, pp. 89-107.

[27] E. G. Ravenstein, “The Laws of Migration,” Journal of the Royal Statistical Society, Parts 1 and 2, Vol. 48 and Vol. 52, 1885 and 1889, pp. 167-227 and pp. 241-301, Respectively.

[28] H. S. Shryock Jr., "The Efficiency of Internal Migration in the United States," Proceedings of the International Population Conference, Vienna, 1959, pp. 1-10.

[29] P. E. Graves and D. M. Waldman, "Multimarket Amenity Compensation and the Behavior of the Elderly," American Economic Review, Vol. 81, No. 5, 1991, pp. 1374-1381.

[30] M. J. Greenwood, J. A. Chalmers and P. E. Graves, "Regional Location Patterns in the United States: Recent Changes and Future Prospects,” In: J. van Dijk, H. Folmer, H. W. Herzog Jr. and A. M. Schlottmann, Eds., Migration and Labor Market Adjustment, Kluwer Academic Pub- lishers Group, Berlin, 1989, pp. 3-45.

[31] P. E. Graves and J. Regulska, “Amenities and Migration over the Life-Cycle,” In: D. B. Diamond and G. S. Tolley, Eds., The Economics of Urban Amenities, Academic Press, New York, 1982, pp. 210-221.

[32] K. Jackson, "Crabgrass Frontier. The Suburbanization of the United States,” Oxford University Press, Oxford, 1985.

[33] E. S. Mills and L. S. Lubuele, “Inner Cities,” Journal of Economic Literature, Vol. 35, 1997, pp. 727-756.

[34] J. K. Brueckner, J.-F. Thisse and Y. Zenou, "Why Is Central Paris Rich and Downtown Detroit Poor? An Amenity-Based Theory," European Economic Review, Vol. 43, No. 1, 1999, pp. 91-107. doi:10.1016/S0014-2921(98)00019-1

[35] P. E. Graves, “Nonoptimal Levels of Suburbanization,” Environment and Planning A, Vol. 35, No. 2, 2003, pp. 191198. doi:10.1068/a3577

[36] W. C. Wheaton, "On the Optimal Distribution of Income among Cities,” Journal of Urban Economics, Vol. 3, No. 1, 1976, pp. 31-44. doi:10.1016/0094-1190(76)90056-5

[37] M. Fujita, “Urban Economic Theory,” Cambridge University Press, Cambridge, 1989. doi:10.1017/CBO9780511625862

[38] P. E. Graves, “A Note on the Valuation of Collective Goods: Overlooked Input Market Free Riding for Non-Individually Incrementable Goods," The B.E. Journal of Economic Analysis and Policy, Vol. 9, No. 1, 2009, pp. $1-17$.

[39] N. Flores and P. E. Graves, “Optimal Public Goods Provision: Implications of Endogenizing the Labor/Leisure Choi- 
ce,” Land Economics, Vol. 84, No. 4, 2008, pp. 701-707.

[40] P. A. Samuelson, "The Pure Theory of Public Expenditures,” Review of Economics and Statistics, Vol. 36, No. 4, 1954, pp. 387-389. doi:10.2307/1925895

[41] E. H. Clarke, "Multipart Pricing of Public Goods," Public Choice, Vol. 11, No. 1, 1971, pp. 17-37. doi:10.1007/BF01726210

[42] T. Groves and J. O. Ledyard, "Optimal Allocations of
Public Goods: A Solution to the 'Free Rider' Problem," Econometrica, Vol. 45, No. 4, 1977, pp. 783-809. doi: $10.2307 / 1912672$

[43] P. E. Graves, "The Simple Analytics of the WTA-WTP Disparity for Public Goods,” Manuscript, 2009.

[44] C. Tiebout, “A Pure Theory of Local Expenditures,” Journal of Political Economy, Vol. 64, No. 4, 1956, pp. 416-424. 